\author{
Eleonora Jedlińska \\ ๑ https://orcid.org/0000-0002-4322-5563 \\ Institute of Art History, University of Łódź \\ eleonora.jedlinska@uni.lodz.pl
}

\title{
A DISCOURSE BETWEEN AND ABOUT TWO ARTISTS: ALBERTO GIACOMETTI AND FRANCIS BACON
}

\begin{abstract}
The major problem of this argument is the principal meaning of the notion of discourse with reference to the life, work (which is very important in this case) and mutual relations between two outstanding artists of the 20th century: Alberto Giacometti and Francis Bacon. Discourse on these artists was taken up by the art critics, curators and collectors who organized an exhibition confronting their oeuvre in 2018, and, as I try to demonstrate in this text, by the artists themselves. ${ }^{1}$ A similar artistic attitude, lifestyle, bond of friendship, rivalry and creative visions formed the relationship between Giacometti and Bacon. They were artists who had a fundamental influence on the shape of contemporary art. The problem of discourse links their work, art and fascination with photography shared by both of them. A special place is given to their adoration of the art of old European masters, similar fates and tastes, the creative research community that existed between them and discourse revolving around their lives. The joint presentation of the works of the two artists, Bacon and Giacometti, within one exhibition, allowed us to see their artistic achievements and fates from the perspective of understanding the meaning of the notion of discourse. An exhibition of their works took place in 2018 at the Beyeler/Basel Foundation in collaboration with the Giacometti Foundation in Paris. The show became a substantive visual indication of a particular discourse between and about the lives and works of Giacometti and Bacon.
\end{abstract}

Keywords: Francis Bacon, Alberto Giacometti, discourse, creative process, sculpture, painting, human figures, studio.

1 Bacon-Giacometti, Fondation Beyeler. Fondation Giacometti, Riehen/Basel, April 29September 2, 2018, (ed.) C. Grenier, U. Kuster, M. Pappiatt, pp. 19-20. 
The notion of discourse (Latin discursus - "running about", "back and forth"), derived from linguistics, denotes a form of language organisation. Nowadays it is sometimes used interchangeably with such terms as conversation or discussion/dispute (obsolete). According to the Polish Language Dictionary, discourse is "a discussion on scientific matters"; "reasoning according to a chain of strictly logical deductions". According to Webster's Third New International Dictionary of the English Language Unabridged, ed. by Könemann, Sprinfield, Mass USA 1993, p. 647, the notion of "discourse" in its basic meaning is derived from the archaic: 1 . the act, power, or faculty of thinking consecutively and logically: the process of proceeding from one judgment to another in logical sequence; the reasoning faculty $\mathrm{b}$ : rationality; capacity of proceeding in an orderly and necessary sequence - used chiefly in the phrase discourse of reason; 2. progression or course esp. of events: course of arms: combat; 3 a: verbal interchange of ideas; $b$ : an instance of such interchange; 4 a: the expression of ideas; $b$ : a talk or piece of writing in which a subject is treated at some length usu. in a orderly fashion; 5 a: power of conversing: conversational ability; b: account, narrative, tale; c: social familiarity with a subject; 6 . linguistics: connected speech or writing consisting of more than one sentence..."

These days, "discourse" more and more often refers to language understood as a socially situated process; it serves a constructive function of systematising knowledge and related social, and institutional practices. In this sense, discourse is a method of expressing reality - explaining, but also influencing it. In this sense, it is therefore necessary to frame the concept in terms of what we understand as conversation.

$*$

A similar artistic attitude, lifestyle, bonds of friendship, rivalry and creative visions built up a relationship between Alberto Giacometti and Francis Bacon, the artists who had a fundamental influence on the shape of art in the second half of the 20th century. The discourse linking their art, shared fascination with photography, adoration of the art of old masters, similar fates and tastes, the community of creative research that existed between them (interrupted by Giacometti's death in 1966), but also the discourse revolving around their lives, became the subject of their friends' memories, research papers, exhibitions and analyses of their art. ${ }^{2}$ The phenomenon of discourse between the artists, or rather intense conversation between them, is contained in their understanding

2 See: Isabel Rawsthorne: draft unpublished autobiography, ca. 1985, private collection: M. Harrison, exh. cat. Alberto Giacometti, Francis Bacon: Isabel Rawsthorne and Other Intimate Strangers, Gagosian Gallery, New York 2008; Bacon-Giacometti, Fondation Beyeler. Fondation Giacometti, Riehen/Basel, April 29-September 2, 2018, (ed.) C. Grenier, U. Kuster, M. Pappiatt. 
of what the matter of art (a human and animal figure, a photograph, an object, the subject of death, the effect of framing space, the studio as a workshop, a frame, the centre and, most importantly, the optical point) meant for them.

Thanks to the joint presentation of the works of the two artists, Francis Bacon and Alberto Giacometti, within one exhibition, we can see their artistic achievements and turn of fate from the perspective of understanding the meaning of the notion of discourse, understood as a particular, logically shaped sequence of understanding and agreement. [Fig. 1] Their friendship, mutual fascination and art (though stylistically different) was based on the exchange of ideas, as well as similarities and parallels between them. Both Bacon and Giacometti believed that a work of art must depict a human figure; they valued the achievements of the same great artists of old European art, whom they both copied and paraphrased. What was important for both artists was the use of the image of a human being, i.e. a portrait of a body transposed from a photograph or a model into a sculpture or a painting, as well as incorporating "frames" into the work, which was a method of isolating the figure from its surroundings. In a letter to Pierre Matisse, Giacometti wrote about his fascination with Tintoretto's painting: In 1920-1921 I was in Italy. First in Venice, where I spent my time mainly looking at Tintoretto, as I didn't want to miss a single painting. ${ }^{3} \mathrm{He}$ goes on to write about Giotto's and Cimabue's frescoes that he saw in Assisi. In a conversation with David Sylvester, Bacon recalls Cimabue's painting Crucifixion of 1287-1288 (now stored in the Museo dell'Opera di Santa Croce in Florence), a reflection of which - very transfigured - is found in the right wing of the 1962 work Three Studies for a Crucifixion. ${ }^{4}$ They both admired Velízquez, Rembrandt, Cézanne, Vincent van Gogh, Pablo Picasso, etc.

The conviction that the works of the old masters had fundamental importance for modern art was revealed in Giacometti's and Bacon's works depicting the human being, painting/sculpting from a model and using photography as a tool. They were not interesting in abstract painting which dominated immediate post-war years. Having witnessed the events of the First and Second World War, both of them, according to the organisers of the Bacon-Giacometti exhibition, were marked by the crisis of humanity. Thus, the principle of their work was to reach and discover the very essence of individual existence of the individual with

3 List do Pierre'a Matisse'a / Lettre a Pierre Matisse, transl. M. Kędzierski, «Kwartalnik Artystyczny» 2003, nos. 2-3, p. 27. First edition: Hier, sables mouvant, "Le Surrealisme au Service de la Revolutuion"» 15.5.1933; reprint: A. Giacometti, Ecrits, Hermmann, Paris 1990.

4 D. Sylvester, Interviews with Francis Bacon. The Brutality of Fact. London: Thames \& Hudson, 1987, pp. 14-15. 


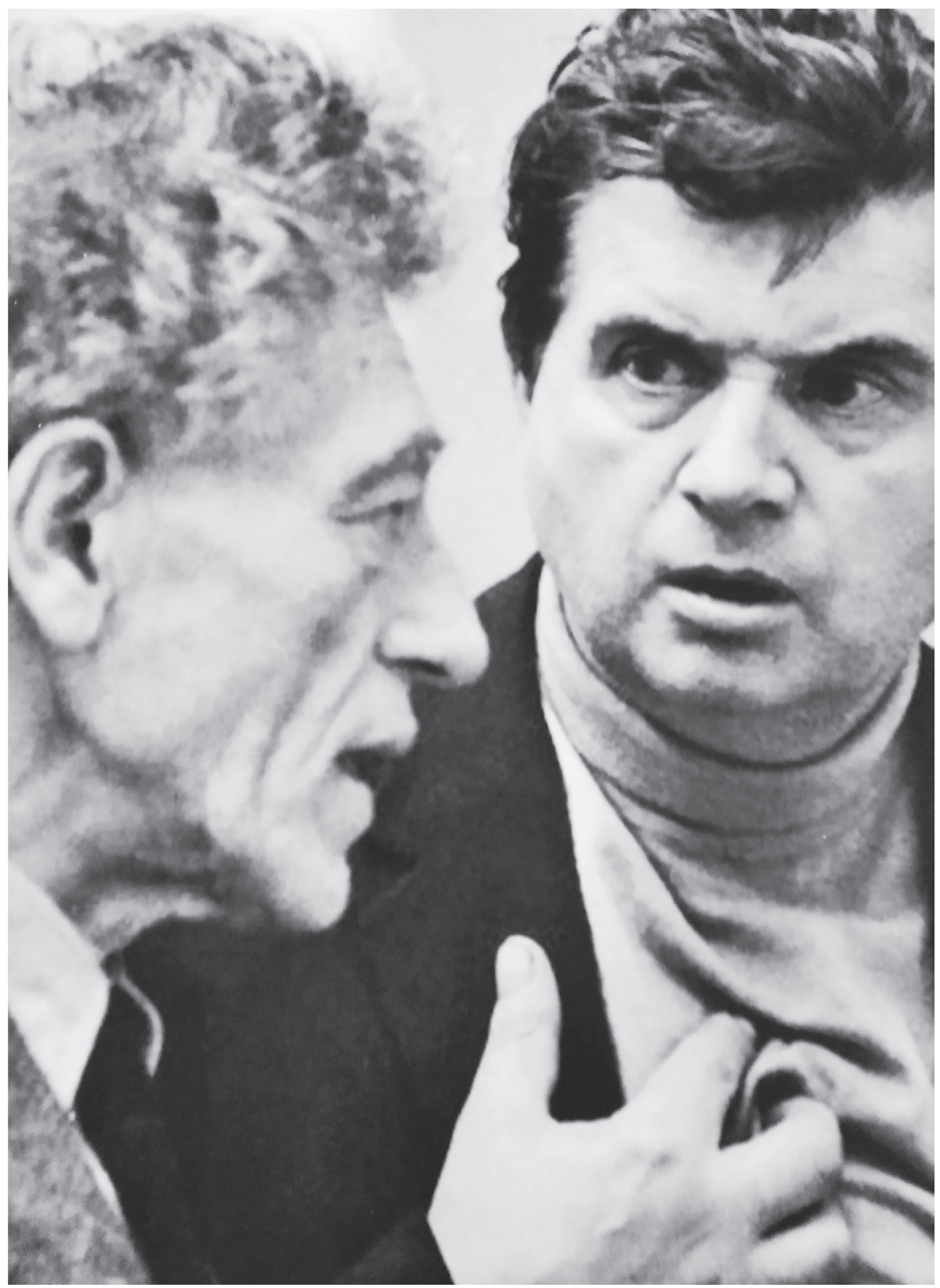

1. Alberto Giacometti and Francis Bacon at the Tate Gallery, London, 1965, photographed by Graham Keen. Source of photograph: catalog exposition Bacon. Giacometti, Fondation Beyeler. Foundation Giacometti, Riehen/Basel, April 29 - September 2, 2018, p. 23. 


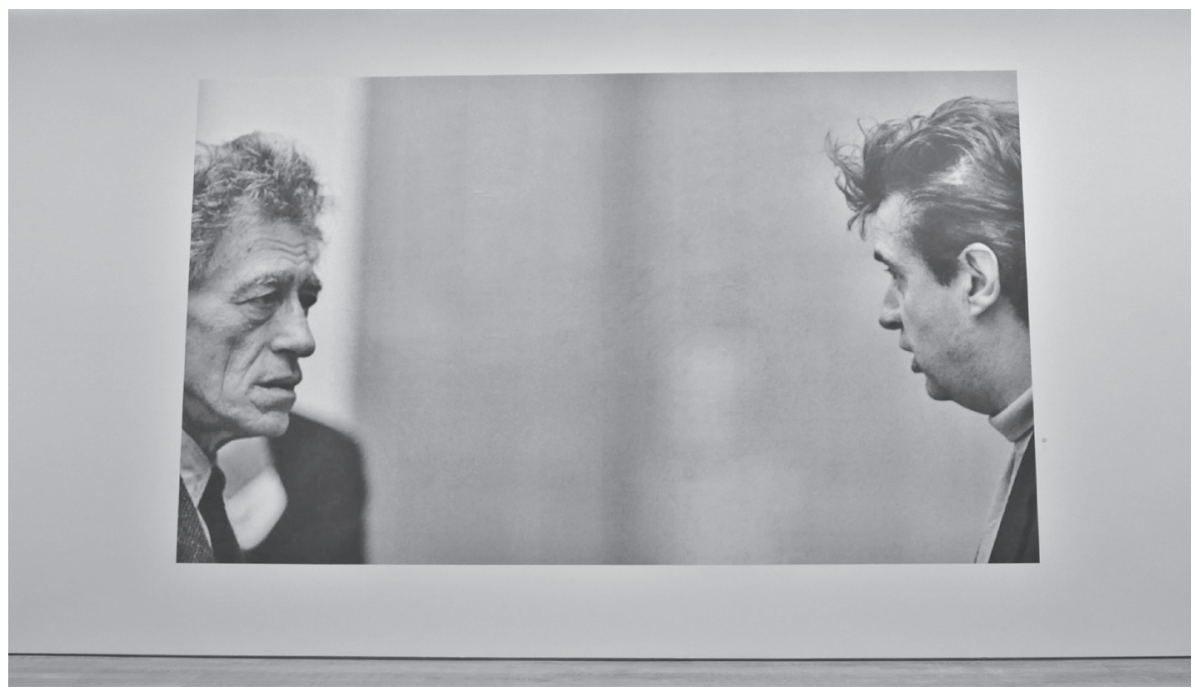

2. Alberto Giacometti and Francis Bacon at the Tate Gallery, London, 1965, photographed by Graham Keen.

its fears, suffering, loneliness, sexuality, fear of life and death. They were fascinated with a fragmented "injured" human and animal body which, in spite of their far-reaching and often extreme abstractness, always remained within the limits of representability in their works; they both called themselves "realists".

Analogies between them can be also found in similar motifs they used in art, their artistic tastes, in their conviction that the most important place in which a work of art is created is thought. Thierry Dufrêne called Giacometti's studio-workshop 'the skull of the artist': His studio is above all a mental, imaginary space. It may be small but it is as big as the universe!. ${ }^{5}$

They both created in small cluttered studios, treating them as a place for their inspiration and creative power, combining intense work with the intensity of life. Both of them were addicted to alcohol. Giacometti was a notorious smoker and a frequenter of Paris brothels, while Bacon boldly declared his homosexuality at the times when, according to the British law, homosexuality was punished by imprisonment. He was also a compulsive gambler and a frequenter of night clubs, immersed in guilt and inner loneliness. ${ }^{6}$ Most importantly, they both created art beyond their times, stemming from a conviction of their

T. Dufrêne, Alberto Giacometti: les dimensions de la realite, Skira, Genève 1994, p. 119.

See: S. Ofield, Wrestling with Francis Bacon, "Oxford Art Journal” 2001, vol. 2, pp. 113-130;

P. Leszkowicz, Homoseksulany Bacon, "Kwartalnik Artystyczny” 2005, no. 4, pp. 114-123. 
own otherness and, at the same time, imperfection, isolation and distance from external reality, using Giacometti's words from a letter to Pierre Matisse. ${ }^{7}$ They both functioned among the circles of the most important artists and intellectuals of the avant-garde, were fascinated by the same books and masters of old art. They both gained fame during their lifetime and their art was appreciated around the world. The special coincidence of art, life and the intellectual attitude of both artists - noticed by curators, collectors, and art historians all over the world - resulted in the creation of exhibitions whose leitmotif is the phenomenon of convergence of both artists' lives on many levels, including their work.

They met in the early 1960s in Paris during Bacon's stay in the French capital. [Fig. 2] Francis Bacon (born in 1909), eight years younger than Alberto Giacometti (born in 1901), approached the sculptor and said how much he admired his work. The Englishman liked the lifestyle of Giacometti who, despite his popularity and concomitant wealth, continued to work in his small studio near Montparnasse. Bacon also shared Giacometti's lack of interest in official honours and success.

Presenting both artists, I would like to focus on their creative personalities and individual characters which posed questions that (despite our inquiries) are still not answered. Their oeuvre, so formally different and often encompassing philosophical and existential dilemmas, remained isolated against the background of streams present in 20th-century art, and marked out the paths followed by others. They were representatives of the generation of artists who believed that art could "tell the truth", representing reality as it is.

\section{Alberto Giacometti - the studio as the thought, space and axis mundi: Paris rue Hippolyte-Maindron /Institute Alberto Giacometti, rue Victor Schoelcher}

The Swiss artist's sculptures first became popular among the writers: Michel Leiris $^{8}$ and André Breton ${ }^{9}$ in the late 1920s. The first biography of Alberto Giacometti was written by Reinhold Hohl ${ }^{10}$ whose monograph, published in 1971, later on became the basis for further study. ${ }^{11}$ Hohl supported his rese-

7 List Giacomettiego do Pierre'a Matisse'a, transl. M. Kędzierski, "Kwartalnik Artystyczny" 2005 , no. 4, p. 35 (page 5 of the letter). Reprinted in the catalogue of the exhibition at the Pierre Matisse Gallery, New York Alberto Giacometti: Exhibition of sculptures, paintings, drawings. Introduction by Jean-Paul Sartre, and a letter from Alberto Giacometti. January 19 to February 14, 1948, reprint: Albert Giacometti, Ecrits, Hermann, Paris 1990. 
arch, exegesis and interpretation of Giacometti's life and work with an analysis of literary texts by the French poet, philosopher and literary and art theorist Yves Bonnefoy ${ }^{12}$, and the art historian Thierry Dufrêne. ${ }^{13}$ Dufrêne was the author of a monograph published in 1994 and co-founder of the Giacometti Institute created in Paris in 2018. ${ }^{14}$ The artist's studio was reconstructed in a restored art deco villa. [Fig. 3] Thanks to an ingenious architectural solution, namely glass walls separating individual rooms, creating intimate zones inside the villa interior, the works can be viewed up close. The Institute's collection currently includes 350 sculptures, 90 paintings and over 2,000 drawings, as well as decorative art objects. It is currently the largest collection of the Swiss artist's works. While maintaining its historical layout and decoration, the interiors of the villa were adapted for the Institute by Pascal Grasso and Pierre-Antoine Gatier. [Fig. 4] Thanks to minimal interventions, the architects created

8 The "photogenicity" of Giacometti's studio began with a session by Leiris who used a series of photographs taken by Marc Vaux for his article-interview with the artist for "Documents" in 1929, showing sculptures positioned in such a way that the images harmonised with the author's words well. See: M. Leiris, Alberto Giacometti, “Documents” 1929, no. 4, p. 210.

9 Between 1930 and 1934, Giacometti was influenced by the Surrealists. In 1935, André Breton excluded him from the milieu and ceased to take interest in him.

10 R. Hohl, Alberto Giacometti, Hatje, Stuttgart, 1971.

11 See: G. Boudaille, Entretien impossible, "Les Lettres françaises", $20-26$ janvier 1966, pp. 1113 (a kind of a casual conversation conducted with people who knew Giacometti); J. Lord, Alberto Giacometti: A Biography, Farrar, Giroux, New York, 1985; R. Hohl, Alberto Giacometti, Nationalegalerie Berlin, 1987; Ch. Doswalds, Alberto Giacometti 1901-1966, Kunsthalle Vienna, 1966; (ed.) R. Hohl, Giacometti: A Biography in Pictures, G. Hatje, Ostfildern-Ruit, 1998. In Poland, the works of the Swiss artist have been written about by, among others: M. Kędzierski (transl.), Alberto Giacometti. Teksty, in: "Kwartalnik Artystyczny” 2003, nos. 2-3, pp. 13-51; M. Kędzierski, Sztuka niezmiernie mnie interesuje... Alberto Giacometti i jego rzeczywistość, in: "Kwartalnik Artystyczny" 2003, nos. 2-3, pp. 83-161; D. Kołacka, Czy portret musi mieć głowę? O Alberta Giacomettiego zmaganiu z materia w kilku częściach, in: "Artium Quaestiones” 2002, no. XIII, pp. 5-74.

12 Yves Bonnefoy (1923-2016) focused his inquiry on the semantic function of the sign, its permanence in places, architecture and painting. He conducted research on French Gothic, Italian Renaissance, European painting from Piero della Francesca to Balthus. In 1991 (reedition in 2018), he published Alberto Giacometti: biograhie d'une oeuvre unique, ed. Flammarion, Paris 2018.

13 See: T. Dufrêne, Alberto Giacometti: Les dimensions de la réalité, Skira, Gèneve 1994; (ed.) Nadia Schneider, Thierry Dufrêne, Donat Rütiman, Casimoro Di Crescenzo, Alberto Giacometti: Retrospective, JRP Riniger, 2010.

14 The Giacometti Institute in Paris holds thematic temporary exhibitions. Alberto Giacometti's studio was recreated on the ground floor of the restored villa at 5, rue Victor Schoelcher (Montparnasse), dating from 1912 to 1914 and formerly owned by the artist, and interior designer Paul Fallot. The furnishings of the studio were donated by the widow of the artist, Annette Giacometti. Among the works collected, there are plaster and clay sculptures that have never been shown before. The walls painted by Giacometti, as well as the furniture and equipment used by the artist in his everyday life have been transferred from the studio in Hippolyte-Maindron. 


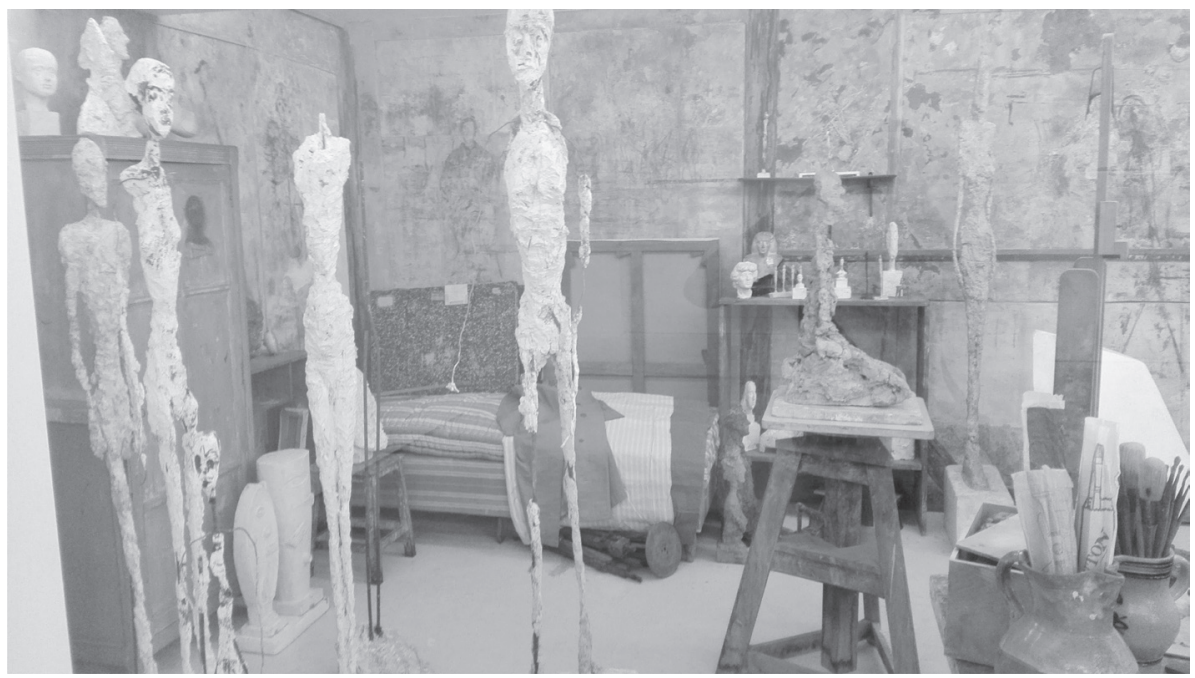

3. Alberto Giacometti's reconstructed studio on 46, rue Hyppolite-Maindron in Paris (Montparnasse). Institute/Fondation Alberto Giacometti 5, rue Victor Schoelcher (Montparnasse). Source of photograph: the photo comes from the author's archive

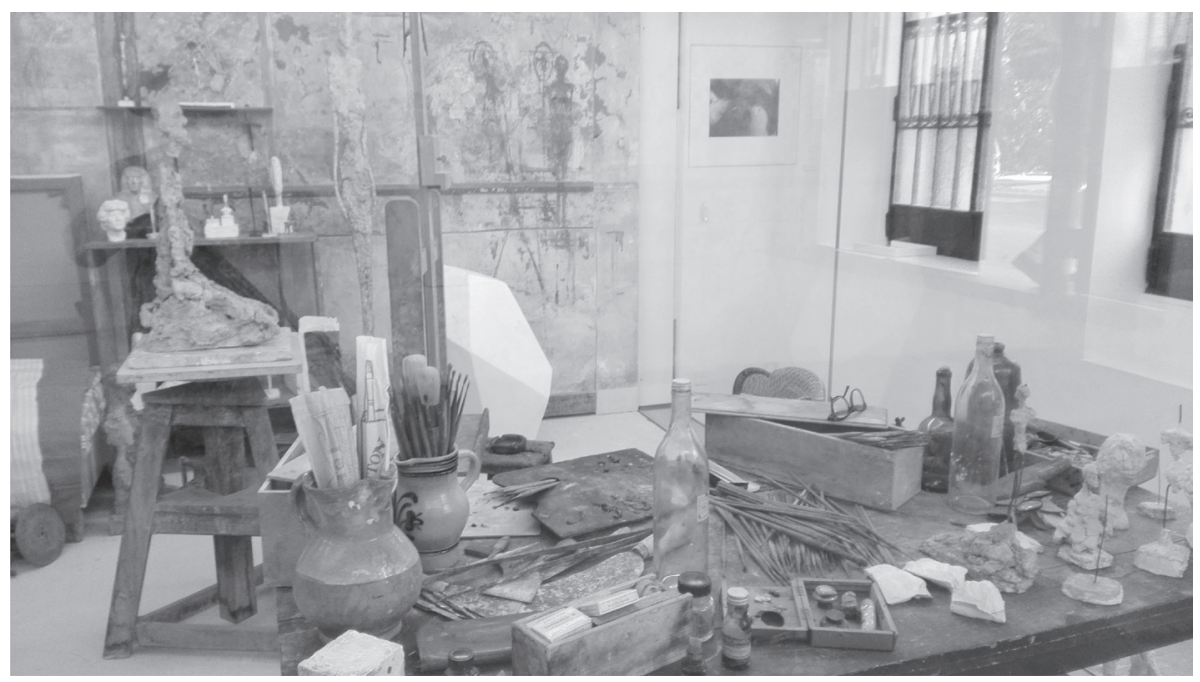

4. Alberto Giacometti's reconstructed studio on 46, rue Hyppolite-Maindron in Paris (Montpar nasse). Intitute/Fondation Alberto Giacometti 5, rue Victor Schoelcher (Montparnasse). Source of photograph: the photo comes from the author's archive. 
a kind of a labyrinth whose leitmotif is the displayed works, relating to the theme of the current exhibition (e.g. Giacometti - Genet; Giacometti - Bacon; Giacometti - Picasso). ${ }^{15}$

In the artist's studio there was a small mezzanine floor accessible via stairs. He used its slant as a frame for his painted figures. ${ }^{16}$ Giacometti's studio was a place of work, meetings and intellectual inquiry, but also one where he built the optics of his works; it was, according to Dufręne, a kind of camera obscura. Giacometti would "see" a drawing, a painting, a sculpture in the frame of his studio before it was created; he worked to some extent like a photographer. The cramped studio interior played the role of a frame: on the floor, the artist drew lines-screens within which he placed the model. ${ }^{17}$ It was also, according to Véronique Wiesinger, curator of the Paris exhibition L'atelier d'Alberto Giaco$m e t t i$, his head, his thinking and imagining; he did not need space. Giacometti's work is created in a special, almost tender relationship with the model, the object. This attitude, which determined his system of work, has been preserved in the recreated studio at the Giacometti Institute in Paris.

The same authors who wrote about Giacometti were also interested in Bacon's life and painting. While reviewing essays and treatises devoted to both masters, we come across the same names: Michel Leiris, David Sylvester, Michael Peppiat, Marek Kędzierski. The moment when the Swiss artist from Montparnasse and the Dublin-born Englishman met seems to have been preceded by a network of people who, in their art and life, perceived unique unifying discourse as the building block of narratives about and between the two great artists of the 20th century.

Giacometti's work was described by Jean Genet, a friend of the artist: ${ }^{18}$ they met in 1954 through Jean Paul Sartre, when they both were already famo-

15 The Institute is headed by Catherine Grenier, curator and art historian, former deputy director of the Centre Pompidou. She aims to present particular aspects of Giacometti's work, his relationships with artists and writers, and the use of photographs that were of great importance to him. It is worth mentioning that Giacometti was friends with, among others, Cartier-Bresson, Inge Morath, René Burri, Robert Doisenau, Sabine Weiss, Gordon Parks, Ernst Scheidegger, Jean-Paul Sartre and Samuel Beckett.

16 T. Dufrêne : «Pour Giacometti, l'atelier est un lieu mental et de réglage optique » - L'ŚIL - n 596 (lejournaldesarts.fr) (30.5.2021).

17 See the exh. cat. V. Wiesinger, L'atelier d'Alberto Giacometti. Collection de la fondation Alberto et Annette Giacometti, Édition du Centre Pompidou Paris, 2007. Véronique Wiesinger headed the Albert and Annette Giacometti Foundation established in 2003.

18 J. Genet, L'Atelier d'Alberto Giacometti, French \& European Pubns, 2017. The first edition was published in 1958 by Éditions L'Arbalète. In 2018, from June 26 to September 16, the Giacometti Institute in Paris held an exhibition titled L'Atelier d'Alberto Giacometti vu par Jean Genet. 
us and renowned. Genet often visited the studio at Hyppolite-Maindron and, between 1954 and 1957, he posed for portraits on several occasions. When the artist painted Genet's portrait in 1954 or 1955 (now in the collection of the Tate Gallery in London), using his characteristic sparse palette of colours, he gradually built the image of the writer by applying small, timid layers of paint on the canvas: this technique creates a tense, 'shifting' contour around the figure, reminiscent of the heavily worked surfaces of Giacometti's sculptures. ${ }^{19}$

In Polish bibliography, Marek Kędzierski's studies on Alberto Giacometti and translations of the artist's words are an invaluable source stemming from Kędzierski's fascination with Giacometti's work, sensitivity and deep understanding of his artistic and spiritual attitude..$^{20}$

Alberto Giacometti was born in October 1901 in Borgonovo, Switzerland, near Stampa (the Bregaglia Valley). The area was mainly inhabited by highlanders speaking an Italian dialect. In March 1922 he arrived in Paris. At the turn of 1924, he rented his first studio on avenue Denfert-Rochereau. After a year, he moved to an atelier on the second floor on rue de Froidevaux, overlooking the Montparnasse cemetery. It was not until the spring of 1927 that he settled at the place that became his studio and home. The cramped atelier (as seen in the photographs) on 46, rue Hippolyte-Maindron in the 14th district (Montparnasse) became the centre of his life and art. This place did not have electricity or sanitary facilities. It had running water, but the toilet was in the courtyard.

The studio was a place (...) that met the needs of a budding sculptor. Quite a high room with bare walls and a rough concrete floor had a large north-facing window, and took up no more than 20 square metres in total. A sleeping area was arranged in the corner on the wooden mezzanine and later a small bedroom was added. ${ }^{21}$ Everything else was marginalised, wrote Thierry Dufrêne. ${ }^{22}$ The artist remained there until his death in 1966.

Alberto was the son of the painter Giovanni Giacometti. His father instilled in him respect for tradition, masters of European art and the principle of

19 'Jean Genet', Alberto Giacometti, 1954 or 1955 | Tate (31.5.2021).

20 See: M. Kędzierski, 'Sztuka niezmiernie mnie interesuje...' Alberto Giacometti i jego 'rzeczywistość", "Kwartalnik Artystyczny" 2003, nos. 2-3, pp. 83-161; M. Kędzierski, "Widzieć" oznaczato dla niego "być”... James Lord w rozmowie z Markiem Kędzierskim, transl. Marek Kędzierski, "Kwartalnik Artystyczny" 2003, nos. 2-3, pp. 163-191; M. Kędzierski, "My byliśmy uprzywilejowani..." Ernst Scheidegger w rozmowie z Markiem Kędzierskim, transl. Marek Kędzierski, "Kwartalnik Artystyczny" 2003, nos. 2-3, ds. 192-202. In 2002, the 13th issue of the Poznan "Artium Quaestiones" published an extensive fragment of Daria Kolacka's thesis Czy portret musi mieć głowę? O Alberta Giacomettiego zmaganiu z materia w kilku częściach, pp. 5-75.

21 M. Kędzierski, 'Sztuka niezmiernie mnie interesuje...' Alberto Giacometti i jego "rzeczywistość", "Kwartalnik Artystyczny" 2003, no. 2-3, p. 98. 
depicting like realists, impressionists, or Cézanne. In Paris, Alberto first took up five years (1922-1927) of studies at the studio of Antoine Bourdelle. At that time, he came closer to Cubism (1925-1929). The desire to depict a whole figure at once, to capture its "real presence", register the detail seen and the impossibility of grasping the whole, similarity, of giving it life, led him towards the Surrealists. This encounter was the reason for breaking away from Bourdelle's teachings, from "external" "geometric" realism (cubist studies). Surrealism led Giacometti towards "internal" realism. ${ }^{23}$ The encounter with the Surrealists, with the prose of Georges Bataille, Michel Leiris and Raymond Queneau, their fascination with the negation of bourgeois values, uniqueness of truth and undermining the meaning of the whole Western culture, influenced Giacometti's attitude for a short time. Raised in the Calvinist tradition, having a strong sense of the permanence of family ties, he opposed the understanding of freedom that Paris offered him. He started searching for meanings and authenticity hidden or concealed under the glitter of the world. Other manifestations of Surrealism (unconsciousness, discrediting reality, predilection for destruction) were alien to him. In June 1933, the artist's father, painter Giovanni Giacometti, died. His father's death triggered a desire to do something that would allow him (after the so-called Surrealist period) to return to the human figure, to figurative art and to work with a live model. At the turn of 1935, Alberto finally parted ways with the Surrealists. However, a radical turn in his work did not occur until around 1937. Around 1940, Giacometti began making smaller and smaller figures placed on huge plinths. ${ }^{24}$

\section{Francis Bacon: the atelier as a battlefield (7, Reece Mews in London) $)^{25}$}

"1 feel at home here in this chaos because chaos suggests images to me. And in any case 1 just love living in chaos. (...) 1 do like things to be clean, 1 don't want

22 T. Dufrêne, Alberto Giacometti: Les dimensions de la réalité, Skira, Gèneve 1994, p. 111.

23 Giacometti's encounter with African sculpture: bold reductions of forms characteristic for cubists. In African art, he tries to get to the essence of the processes of its formation and its meanings - not only aesthetic, but also related to the essence of its magical, mystical functioning in the area of African peoples' culture. Cf.: Y. Bonnefoy, Alberto Giacometti. La biographie d'ouevre, ed. Flammarion, Paris 1991.

24 Yves Bonnefoy argues that the reason for this reduction is the desire to reproduce the human figure in its entirety. Only seeing it from a distance can produce the desired effect. See: Y. Bonnefoy, Alberto Giacometti..., op. cit., p. 556.

25 My extensive article, which includes Bacon's bibliography, presents his biography, friendships, the importance and role of the works of great European masters, well as the artist's use of photography as a tool of his work, was published in "Szuka i Krytyka" in 2021. See: E. Jedlińska, Francis Bacon (1909-1992). Fotografia jako sposób patrzenia, "Sztuka i Krytyka" 2021, nos. 3-4, pp. 8-32. 


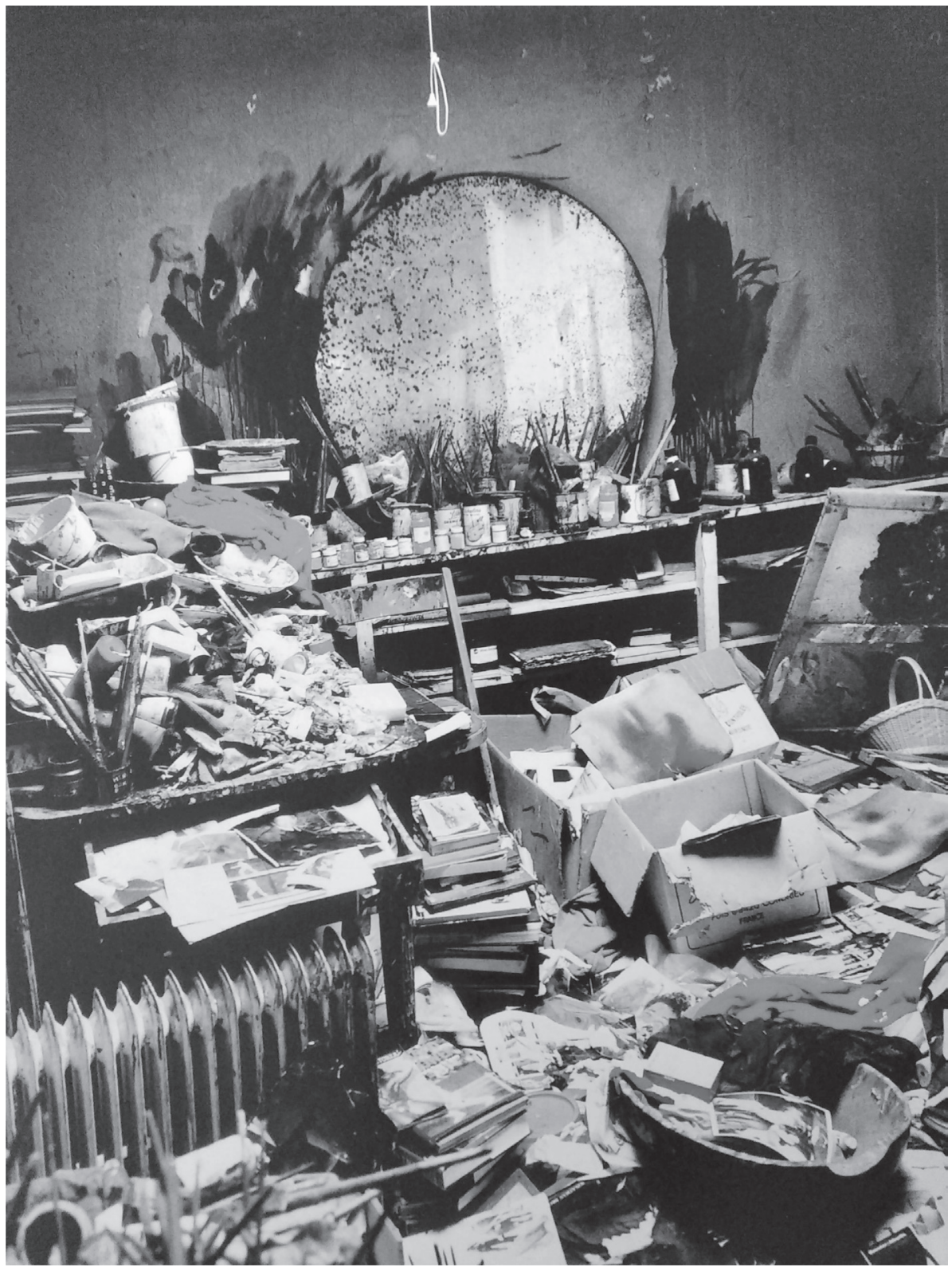

5. Francis Bacon's Studio. 7, Reece Mews in London. Source of photograph: the photo comes from the author's archive. 
the plates and things to be filthy dirty, but 1 like a chaotic atmosphere". ${ }^{26}$ [Fig. 5]

In all probability, materials found at the studio on 7, Reece Mews after the painter's death are the only ones that reliably reconstruct the Irish artist's life and work from 1961 onwards. Bacon did not pay much attention to paintings or materials left at his previous places; he threw away those considered unnecessary. He only took crucial documents to his last studio and those retrieved from under the abandoned piles of paper cannot be treated in any way as a systematically maintained archive. Materials collected over the years, lying on the studio floor, were simply thrown away when their sheer volume made work impossible or when they seemed unnecessary and disturbing. Chaos at Bacon's studio was, to a certain extent, a reflection of the way he worked: he believed that order should be reflected in his paintings, through pedantry with which they were framed and exhibited according to his clearly defined guidelines. The studio, visited by the painter's friends, a close circle of photographers and critics, was located in South Kensington (a London district). Its collections, however, had not been explored until the artist's death. Bacon did not keep an orderly archive, neither did he catalogue his works or the materials constituting, as mentioned above, the tools of his paintings. In 1992, after the artist's death, the archive was taken care of first by Valerie Beston and then by John Edwards $^{27}$, his friend and executor of his will, who donated the archive collection and the works to Dublin City Gallery, The Hugh Lane. The studio was located in a small room, measuring $6 \times 4$ metres, filled with piles of photographs, books, albums, magazines, sketches and finished paintings. ${ }^{28}$ Art historians undertook to research and reveal what was hidden under the layers of materials accumulated over thirty years. Hidden does not mean obscured - the papers lay at the studio, forming a specific palimpsest of the artist's work, experiences, current and past fascinations, hesitations, abandonments and returns to his topics. "What was hidden came to light, what was under the layers proved to be as important to Bacon as what was visible"29. Some of the papers were torn on purpose, other works were consumed by time, smeared with paint or pastel, while those depicting someone's face were sometimes deliberately creased or scratched.

26 D. Sylvester, Interviews with Francis Bacon. The Brutality of Fact. London: Thames \& Hudson, 1987, p. 190.

27 John Edwards was Bacon's friend from the mid 1970s, having met the artist at London's Colony Club in 1974 through his brother, who was friends with Muriel Belcher. Bacon made Edwards his sole heir. He is the subject of several Bacon's portraits, including Portrait of John Edwards from 1988.

28 It is worth mentioning at this point the exhibition that took place in Paris at the Centre Pompidou in 2019/2020 Bacon. En toutes lettres, Francis Bacon. Books and Painting (See: D. Ottinger 2019-2020).

29 B. Dawson, Tracing Bacon, in: Francis Bacon. Incunabula, Thames \& Hudson, London 2009, p. 5. 
The materials come from different periods of Bacon's life, some from the time when, after years of living in different places, he settled in October 1961 at a studio located on the first floor of a house at 7, Reece Mews in London, where he stayed until his death. Books, magazines, various prints on medical issues, bullfighting, manuals on gardening, boxing, animals, as well as reproductions of his own paintings filled the cramped interior. The publications collected by Bacon were torn apart by him, he cut out individual articles and photographs, folded loose pages, added over or underlined some parts. He concealed his working methods and the method of creating his paintings, which were known only to his close friends.

The studio at 7, Reece Mews was frequented in the 1970s by journalists taking photos of its interior and today these photographs are a valuable resource for examining the last thirty years of Bacon's work. They show a colourful modest room cluttered with shelves containing piles of books, stacks of cardboard boxes filled with photographs and loose pages from magazines and books. A painting / reproduction / photograph could be useful to Bacon only when the expected association was formed in his mind; when he transformed it into his own work of art, the image became unnecessary, it disturbed him and had to be got rid of, closed in a box, so as not to interfere with the painting process itself.

A portrait of Muriel Belcher ${ }^{30}$ by John Timbers (c. 1965 and c. 1975), found among the numerous photographs, shows how Bacon inserted his own interventions into photographs, adding or repainting elements (here: a rectangular mirror painted white, which, like in Ingres's paintings, reflects the back of the model's head and profile, painted so as to become a shadow, contrasting with the light matt background). Bacon painted Muriel Belcher on numerous occasions (e.g. Miss Muriel Belcher, 1959; Three Studies for a Portrait of Muriel Belcher (triptych), 1966). She was one of his close friends and her friendship with the artist was uniquely marked and documented by numerous photographs and correspondence. Sphinx-Portrait of Muriel Belcher from 1979, compared with Timbers's photograph, may be an example of the process of association, rejection of selected fragments and transformations of the image-'pattern' taking place in the painter's mind, influencing the final painting. ${ }^{31} \mathrm{~A}$ black and white photographic print has become an extract of the painting. The orange background with a cyclamen-coloured rectangle (an after-image of the mirror in the photograph) on which a deformed figure of the model was placed, enc-

30 Muriel Belcher was the owner of a well-known private club (drinking club) called the Colony Room on Dean Street in Soho, which Bacon liked to visit. Belcher financially supported Bacon and his friends in the 1940s.

31 M. Harrison, R. Daniels, Francis Bacon. Incunabula, London 2008, pp. 10-11. 
losed in a kind of a spatial geometrical frame, with her sphinx claws hooked into orthopaedic rails, suggests a gesture of withdrawal and, at the same time, a desire to stay. The portrait of the friend as a sphinx was painted in 1979, the year of Belcher's death. Thus, one may believe that it was painted on the basis of two photographs: one taken by Deakin around 1965 and another taken by Timbers around 1975. Both photographs were found in folders left at Bacon's studio. The painter's biographer, Harrison, supposes that the portrait of $\mathrm{Mu}$ riel Belcher is a synthesis of both photographs, but also a reflection of scenes remembered from the time of Bacon's visits to the hospital where she was staying. The motif of a sphinx, an outcome of Bacon's fascination with Ingres's picture, was painted by Bacon several times: in 1953, 1954 and 1979. However, as Harrison notes, the exaggerated paws and claws in the 1979 portrait of Belcher, as well as her bare torso also suggest similarity with a photograph published in the Observer of 4 June 1978, showing the dancer Marcia Haydée. ${ }^{32}$ The photo of the dancer, creased and carelessly torn out from the newspaper, was found at Bacon's studio, hence the supposition that it may have served as a kind of a frame for Belcher's portrait. Thanks to materials from Bacon's studio, we also know that the use of surgical rails in Three Studies from the Human Body from 1967 was inspired by a book on medicine by K. C. Clarke, Positioning in Radiography, published in London in 1942. The analysis of sources of the work in question, based on materials found at the painter's last London studio, its structure, composition and the colours used, allowed a closer understanding and, in a sense, unveiled the thought process leading to the final completed painting.

\section{Alberto Giacometti - Georges Bataille - Francis Bacon}

At the same time (the 1920s), Giacometti comes into contact with Georges Bataille. ${ }^{33}$ His History of the Eye "expels the young sculptor from the paradise of certainty in distinguishing between good and evil" - it leads to disintegration of

32 Marcia Haydée Salaverry Pereira da Silva was born on 18 April 1937 in Niterói, Brazil. She was a prima ballerina of the Stuttgart Ballet when the theatre was led by John Cranko, choreographer and ballet director, from 1976 to 1995, and was also director of the Santiago Ballet from 1992.

33 The significance of Bataille's thought for Giacometti's work was analysed by R. E. Krauss, No more play, in: The Originality of the Avant-Garde and Other Modernist Myths, Cambridge, Massachusetts, London 1986, p. 80 et al. Both Giacometti and Bacon were greatly inspired by Bataille's thought. Among other things, both of them - under Bataille's influence - dealt with the condition of the eye looking directly at the sun. The sun, as understood by Bataille, becomes a source of (symbolic and real) blindness, loss of contact with the outside world. Thus, the problem posed in this way negated the modern concept that the pupil connects the soul with the body (p. 80). 
experience of unity, which was guaranteed by the family. ${ }^{34}$ While the safe world with a happy home is disintegrating, Giacometti's attitude becomes more and more filled with uncertainty and fear. His sculptures become focused on the images of death, aggressive sexuality, cruelty, violence and incomprehensible human behaviour. This is exemplified by the so-called "stabbing sculptures" of the 1920s and 1930s (e.g. Man and Woman, 1928-1929; Spoon Woman, 1929; Suspended Ball, 1930; Thorn in the Eye, 1931; Femme égorgé / Woman with Her Throat Cut, 1932). Giacometti's religiosity seems close to Bacon's attitude, yet maybe it is not as explicitly expressed as in the case of the Englishman (e.g. his series of paintings devoted to the Crucifixion). From my standpoint, one of the most important examples of a "religious work" in Giacometti's oeuvre is the sculpture Invisible Object (Hands Holding the Void), 1934. ${ }^{35}$ This sculpture, having an impact equal to that of a "religious" experience, marked the boundaries between Surrealism and the period when the artist refocused on portraiture. It depicts a naked woman with almost natural dimensions and almost preserved proportions of her slender body. The figure is "set" between a standing and sitting position, while the frame of a chair, reminiscent of a Gothic throne, seems to barely support the half-kneeling half-standing position of the body. The long, very slender legs, slightly bent at the knees, are obscured by a board resting against the feet like a kneeler inhibiting all movement. To the right of the "throne", suggesting the support of a railing, we can see the head of a bird with a large open eye. The insect-like arms of the figure, hands with slightly spread fingers extended in a gesture of protective embrace or protection of an invisible object, may express a prayerful state. The representation of the body is relatively naturalistic, while the head has the form of an African mask, a stylized skull or, according to Kędzierski - is simplified to two planes converging at the tip of the chin, with the mouth in the form of a rhomboid cavity and eyes presented as flatly engraved circles: the right one in its entirety, the left one as if damaged (injured) by a sharp object. ${ }^{36}$

Due to this contrast, we can understand/feel this sculpture as a stigma of a-theological "religiosity", all the more universal because the sculptor does not provide it with any attributes. Only its ascetic body, its "injured" deformed head, arms extended in pleading, the half-kneeling position of the female figure, as if slipping from a kneeler-chair, and the enigmatic placement of a bird's head on

34 Y. Bonnefoy, Alberto Giacometti. La biographie d'ouevre, Paris 1991, pp. 177-179.

35 This is probably the first sculpture by Giacometti to represent the entire human figure figuratively. The plaster model was cast in bronze years later. (e.g. the collection of the Hirshhorn Museum and Sculpture Garden, Smithsonian Institution, Washington D.C.).

36 M. Kędzierski, 'Sztuka niezmiernie mnie interesuje...' Alberto Giacometti i jego "rzeczywistość", "Kwartalnik Artystyczny” 2003, nos. 2-3, pp. 111. 
the right side may lead to a "religious" interpretation. This sculpture may be perceived as an image of a primeval idol - an archetype of the propitiatory figure.

When we look at the sculpture in profile, we can notice the forward tilt of the neck and head, which dynamizes emotions and evokes the aspect of expectation. The wound, the injured eye without a pupil, the mouth open in a silent moan and the face profile cut with a sharp fold make the sculpture similar to Bacon's paintings in which he explores the phenomenon of the open mouth. Interpreting this sculpture, Bonnefoy emphasises the effect of imbalance (the naturalistic body and the sensualised head) when we are confronted with something unknown and we want to bring it into the world we know. ${ }^{37}$ The essence of this sculpture is to show the VOID, the absent object that could exist. The empty space between the hands, stopped half leadingly, half fearfully, is at the centre of the void (le vide). The naked ascetic figure is, as Kędzierski notes, devoid of energy. Its "inhuman" presence directs the mind towards the mystery of the invisible, giving it the character of a deity. ${ }^{38}$

Bataille's thought, as mentioned above, exerted a significant influence both on Giacometti and Francis Bacon. Rina Arya ${ }^{39}$ gives a theological analysis of the image of violence, which coincides in both artists' works, as an element of a ritual ultimately leading to the sacred. According to the researcher, both Bataille's writings and Bacon's paintings indicate the sacred recovered in the profane to the reader/viewer:

It is in their works that we experience the primordial theological moment which is the solitude of Crucified Christ and his cry "My God, God why hast thou forsaken me?" Bataille distinguished, among other things, sacrality of the image representing Christ on the cross, calling it "the most sublime of all symbols". 40

Bacon's Three Studies for Figures at the Base of a Crucifixion of 1944 mark a key moment in his artistic journey. It was probably this painting-triptych that established Bacon's position in the art world of the 20th century. He claimed

37 Y. Bonnefoy, Alberto Giacometti. La biographie d'ouevre, Paris 1991, pp. 225-226.

38 M. Kędzierski, op. cit., p. 111.

39 R. Arya, A-theology and the Recovery of the Sacred in Georges Bataille and Francis Bacon, University of Glasgow, Glasgow p. 2. https://ac.uk./en/publication/ A-theology and the recovery of the sacred in Bataille and Bacon - University of Huddersfield Research Portal (31.08.2021)

40 G. Bataille, On Nietzsche, transl. from French: B. Boone, London, Athlone Press, 2000, p. 17. In this work, Bataille considers the question of the presence of violence in Christianity and its concealment, by appealing to the narrative of salvation. 
that what he had done before 1944 was valueless. ${ }^{41}$ Bacon's religiosity is included in two themes with Christian overtones: the Crucifixion motif and "portraits" of popes. Referring to the theme of salvation, taking the central place in Christian theology, Bacon, after all, remains outside religion. His paintings, according to Arya, evoke the absence or death. However, he does not reject Christianity; he provokes question about the existence of the sacred, about the meaning of being "anti-religious" and, at the same time, is fascinated by religious tradition and the art which came into being thanks to religiousness. The painting Three Studies for Figures at the Base of a Crucifixion is a crucifixion without the cross. The lack of the cross in the painting may mean that the artist transfers the point of gravity, the centre of the work to the viewer. It is up to the viewer whether they see the painting as religious or not. In spite of its apparent irreligiosity, Bataille's and Bacon's attitude is deeply religious. They both focus on the injured body of Christ regarded by them as sacred. They reverse the direction of Christian dialogue and, instead of locating the body in the spirit, they locate the spirit in the body. This moment of body revival is profoundly Christian because it is the literal enactment of the incarnation. ${ }^{42}$

\section{$*$}

The interweaving experiences which link the two artists, their similar understanding of the meaning of art, the above-mentioned similar attitude to Christianity ${ }^{43}$, as well as the discourse characterising their attitude marked by mutual admiration, rivalry and the convergence of their disregard for material issues, intriguing for researchers of their work, are reflected in the coincidence of the meaning of their art.

Both Giacometti and Bacon considered the image of the human figure to be their main theme and artistic point of reference. An analysis of the people that both artists portrayed (e.g. Isabel Rawsthorne) may reveal their shared interest in the fragmented and deformed body that yet conveys similarities and individual features. They also both claimed that their art documented reality and, at the same time, bordered on the unrepresentable or crossed this border, situating itself in the areas of the extreme, completely new and abstraction.

41 R. Alley, J. Rothstein, Francis Bacon, London, Trustees of the Tate Gallery, Thames \& Hudson, 1964, p. 11.

42 R. Arya, A-theology and the Recovery of the Sacred in Georges Bataille and Francis Bacon, Université de Glasgow, Glasgow p. 15.

43 This problem is analysed in the article by Rina Arya (see e.g. note 42) and in essays in the catalogue of the Bacon-Giacometti exhibition, Fondation Beyeler. Fondation Giacometti, Riehen/Basel, April 29-September 2, 2018, (ed.) C. Grenier, U. Kuster, M. Pappiatt. See: Catherine Grenier, Violence and Compulsion, pp. 16-23; Michael Pappiatt, Francis Bacon and Alberto Giacometti: Parallel Vision of Terrible Truth, pp. 168-175. 


\section{Giacometti. Bacon. Isabel Rawsthorne - painter - model and friend}

The friendship they both cultivated with the British painter Isabel Rawsthorne was yet another important experience which could have deepened their relationship. Isabel Rawsthorne (1912-1992) played an important role in the lives and work of both artists. She was intriguing, talented and courageous. During World War II, she worked in the so-called "black propaganda" for the Political Warfare Executive (PWE) and during the Italian campaign she edited "Il Mondo Libero". In the 1930s and 1940s, she was in a relationship with Giacometti, sharing a modest studio in Montparnasse with him. Being an artist of an uncommon talent, Rawsthorne attracted him with her original beauty and uncompromising worldview. She shared an interest in the phenomenological and existential implications of representing bodies with Giacometti and Bacon, as Carol Jacobi writes in the "Burlington Magazine". ${ }^{44}$ Giacometti immortalised Isabel in numerous works (including sketches created between 1936 and 1937, and bust sculptures: Tête d'Isabel, 1936 (terracotta); Tête d'Isabel, ca. 1937-1938 (bronze); Tête d'Isabel, ca. 1937-1939 (plaster); Femme au Chariot, ca. 1945 (plaster and wood); Isabel en buste, 1948 (pencil on paper); Femme debout, 1956 (bronze), Figurine, 1953-1954, ca. 1956.45 Bacon's paintings depicting Isabel Rawsthorne come from the 1960s and now they are held at the Staatliche Museen in Berlin, Nationalegalerie (e.g. Three Studies for Portrait of Isabel Rawsthorne, 1965; Study of Isabel Rawsthorne, 1966; Portrait of Isabel Rawsthorne Standing in a Street in Soho, 1967; Study for Head Isabel Rawsthorne, 1967). ${ }^{46}$

\section{Conclusion}

As discussed in this text, the issue of mental discourse regarding both 20th-century master artists, conditioned by their individual lifestyles, is also related to historical, social and aesthetic changes in Europe after 1945. In their lives and work, Giacometti and Bacon framed and reflected the phenomena and problems of the contemporary European reality. At the same time, they

44 C. Jacobi, Picasso's Portraits of Isabel Rawsthorne, "The Burlington Magazine”, 2017 September, vol. 159/No. 1374. https://www.burlington.org.uk/archive/article/picassos-portraits-ofisabel-rawsthorne (30.05.2021).

45 The works by Alberto Giacometti can currently be seen at the Giacometti Foundation in Paris.

46 Between 1964 and 1970, Bacon painted about twenty portraits of Isabel Rawsthorne. Cf. Isabel Rawsthorne: The Women who was a walking Work of Art, 'Yorkshire Post' 15 August 2008. https://www.bing.com/search?q=Isabel Rawsthorne: The Women who was a walking Work of Art, "Yorkshire Post" 15 August 2008. - Bing (31.8.2021). 
were engaged in a specific discourse between and about each other, expressing their times with their art, convictions and attitudes shaping their fates. An encounter with the art of both artists can make us aware of the extent to which their thoughts and works coincided. By analysing their individual works and confronting them with the dates of their creation, themes and, finally, figures they both portrayed, we can recognise references to each of them in the works of the other artist.

Nowadays, there are two very important institutions dedicated to both artists. At the same time, they are places where their works are stored, constituting an archive/library where photographs, documents and exhibition catalogues can be researched. These are the artists' reconstructed studios - places that constituted the centre, "battlefield" and laboratory of their lives and their art. In a book titled L'Atelier d'Alberto Giacometti, dedicated to Giacometti's work and the studio itself, written between 1955 and 1957, Jean Genet ${ }^{47}$ calls the studio a ritual place, a workshop where the artist connects with works of art and ordinary objects located in it. ${ }^{48}$ In 2018, the Institute/Fondation Giacometti was established in Paris at 5, rue Victor Schoelcher, in the Montparnasse district, not far from Giacometti's legendary studio located at 46, rue Hippolyte-Maindron. In addition to holding periodic exhibitions, the institution houses the reconstructed artist's studio and a library related to him. It also organises symposia and film screenings.

In 1998, several years after the artist's death, Bacon's studio was moved from London to Dublin and reconstructed. Currently, his works, archive and all the materials found after his death are gathered in the Dublin City Gallery, The Hugh Lane. The studio was located in a small room, measuring $6 \times 4$ metres, filled with piles of photographs, books, albums, magazines, sketches and finished paintings. ${ }^{49}$

This text is merely an indication of the particular coincidence linking the lives and art of Giacometti and Bacon. The problem evoked here is obviously

47 Jean Genet met Giacometti through Jean Paul Sartre around 1954. He was one of the most attentive recipients of his works, a patient model and interlocutor. Genet's book remains to this day one of the most valuable testimonies of Giacometti's creative process and a unique description of his "universe". In 2018, Giacometti Institute in Paris organised an exhibition around Genet's text, featuring the three main themes most often explored by the poet and sculptor: the studio as a laboratory, images of women and the theme of death.

48 J. Genet, L'Atelier d'Alberto Giacometti, Éditions L'Albèrte, Paris 1958.

49 It is worth mentioning at this point the exhibition that took place in Paris at the Centre Pompidou in 2019/2020 D. Ottinger, Bacon. En toutes lettres, Francis Bacon. Books and Painting, Paris 2019-2020. Didier Ottinger was the curator of the Pompidou exhibition. See: E. Jedlińska, Francis Bacon (1909-1992). Fotografia jako sposób patrzenia, "Sztuka i Krytyka" 2021, nos. 3-4, pp. 8-32. 
much broader. Carrying out an in-depth analysis and interpretation covering various multiple aspects of the links, such as their shared fascination with the art of old masters, photography, literary and philosophical references, but also common friendships and ordinary lifestyles, is a process that requires more detailed research, time and verification of various, often contradictory interpretations by European and American researchers. For an art historian, each of the artists mentioned here is an inexhaustible source of possibilities for research and interpretation, and the life and work of each of them constitute areas which should be constantly explored, provoking a search for linking and dividing discourses, leading to the beginnings and posing a question about the end. Let us remember how important the themes of the human figure, transience and death were for Giacometti and Bacon. These motifs will be the subject of subsequent emerging works devoted to both artists. In future research, it is worth noting friendships they established with the same people who they later portrayed and the irreligiosity of their works that requires deeper analysis, but does not exclude both artists' serious reflection on the meaning and essence of Christianity. These issues were the subject of an ongoing discussion between them and will probably be considered in my future texts devoted to Giacometti and Bacon.

\section{BIBLIOGRAPHY:}

Alley Ronald, Rothstein John (1964), Francis Bacon, London, Trustees of the Tate Gallery, Thames \& Hudson.

Bacon-Giacometti (2018) Fondation Beyeler. Fondation Giacometti, Riehen/Basel, April 29September 2, 2018, (ed.) Grenier Catherine, Kuster Ulf, Pappiatt Michael, pp. 19-20.

Bacon. En toutes lettres, Francis Bacon. Books and Painting (2019-2020), exhibition catalogue Paris at the Centre Pompidou, Paris.

Bonnefoy Yves (1991) Alberto Giacometti. La biographie d'ouevre, Paris.

Bataille Georges (2000) On Nietzsche, trans. from French by Boone Bruce, London, Athlone Press.

Bonnefoy Yves (2018) Alberto Giacometti: biograhie d'une oeuvre unique, ed. Flammarion, Paris.

Boudaille Georges (1966), Entretien impossible, "Les Lettres françaises”, 20-26 janvier 1966, pp. 11-13.

Doswalds Christoph (1966) Alberto Giacometti 1901-1966, Kunsthalle Wiedeń.

Dawson Barbara (2009) Tracing Bacon, in: Francis Bacon. Incunabula, Thames \& Hudson, London. 
Dufrêne Thierry (1994) Alberto Giacometti: les dimensions de la réalité, Skira, Genève.

Dufrêne Thierry (2007) Pour Giacometti, l'atelier est un lieu mental et de reglage optique, Le Journal des Arts.fr 2 novembre 2007.

Genet Jean (1958) L'Atelier d'Alberto Giacometti, Éditions L'Albčrte, Paris.

Genet Jean (2017) L'Atelier d'Alberto Giacometti, French \& European Pubns.

Giacometti Alberto (1990), Ecrits, Hermmann, Paris.

Grenier Catherine (2018) Violence and Compulsion, in: Bacon-Giacometti Fondation Beyeler. Fondation Giacometti, Riehen/Basel, April 29-September 2, 2018, (ed.) Grenier Catherine, Kuster Ulf, Pappiatt Michael, pp. 16-23.

Harrison Martin, Daniels Rebecca (2008) Francis Bacon. Incunabula, London: Thames \& Hudson.

Harrison Martin (2008) exh. cat. Alberto Giacometti, Francis Bacon: Isabel Rawsthorne and Other Intimate Strangers, Gagosian Gallery, New York.

Hohl Reinhold (1971) Alberto Giacometti, Hatje, Stuttgart.

Hohl Reinhold (1987) Alberto Giacometti, Nationalegalerie Berlin.

Hohl Reinhold (ed.) (1998) Giacometti : A Biography in Pictures, G. Hatje, Ostfildern-Ruit.

Jacobi Carol (2008) Alberto Giacometti, Francis Bacon: Isabel Rawsthorne and Other Intimate Strangers, Gagosian Gallery, New York, p. 224.

Jedlińska Eleonora (2021) Francis Bacon (1909-1992). Fotografia jako sposób patrzenia, "Sztuka i Krytyka” nos. 3-4, pp. 8-32.

Kędzierski Marek (2003) (transl.) List do Pierre'a Matisse'a / Lettre a Pierre Matisse, "Kwartalnik Artystyczny" nos. 2-3, p. 27. First edition : N.N., Hier, sables mouvant, "Le Surrealisme au Service de la Revolutuion" 15.5.1933.

Kędzierski Marek (2003) (transl.) Alberto Giacometti. Teksty, in: “Kwartalnik Artystyczny” 2003, nos. 2-3, pp. 13-51.

Kędzierski Marek (2003) Sztuka niezmiernie mnie interesuje... Alberto Giacometti i jego rzeczywistość in: "Kwartalnik Artystyczny", nos. 2-3, pp. 83-161.

Kędzierski Marek (2003) „Widzieć” oznaczało dla niego „być”... James Lord w rozmowie z Markiem Kędzierskim, transl. Kędzierski Marek, "Kwartalnik Artystyczny”, nos. 2-3, pp. 163-191.

Kędzierski Marek (2003) „My byliśmy uprzywilejowani...” Ernst Scheidegger w rozmowie z Markiem Kędzierskim, transl. Kędzierski Marek, "Kwartalnik Artystyczny” nos. 2-3, pp. 192-202.

Kołacka Daria (2002) Czy portret musi mieć głowę? O Alberta Giacomettiego zmaganiu z materiq w kilku częściach, in: “Artium Quaestiones” no. XIII, pp. 5-74. 
Krauss Rosalind E. (1986) No more play, in: The Originality of the Avant-Garde and Other Modernist Myths, Cambridge, Massachusetts, London 1986.

Leiris Michel (1929) Alberto Giacometti, “Documents” 1929, no. 4, p. 210.

Leszkowicz Paweł (2008) Homoseksualny Bacon, “Kwartalnik Artystyczny” 2005, no. 4, pp. 114 -123 .

Lord James (1985) Alberto Giacometti: A Biography, Farrar, Giroux, New York.

Ofield Simon (2001), Wrestling with Francis Bacon, “Oxford Art Journal” vol. 2, pp. 113-130.

Pappiatt Michael, Francis Bacon and Alberto Giacometti: Parallel Vision of Terrible Truth, in: Bacon.Giacometti. exh. cat. Fondation Beyeler. Fondation Giacometti, Riehen/Basel, April 29September 2, 2018. pp. 168-175.

Sylvester David (1987), Interviews with Francis Bacon. The Brutality of Fact. London: Thames \& Hudson.

Sylvester David (1997), Rozmowy z Francisem Baconem. Brutalność faktu, Zysk i S-ka Wydawnictwo, Poznań.

Véronique Wiesinger (2007) L'atelier d'Alberto Giacometti. Collection de la fondation Alberto et Annette Giacometti, eédition du Centre Pompidou Paris.

Internet sources:

Arya Rina (2008) A-theology and the Recovery of the Sacred in Georges Bataille and Francis Bacon, Universite de Glasgow, Glasgow p. 2. https://A-theology and the recovery of the sacred in Bataille and Bacon - University of Huddersfield Research Portal (31.08.2021)

Dufrêne Thierry, Pour Giacometti, l'atelier est un lieu mental et de réglage optique -"L'ŚIL" $n^{\circ} 596$ (lejournaldesarts.fr) https://www.lejournaldeserts.fr/expositions (30.5.2021).

https://www.tate.org.uk/art/artworks/giabometti-jean-genet 'Jean Genet', Alberto Giacometti, 1954 or 1955 | Tate $(31.5 .2021)$.

Isabel Rawsthorne: The Woman who was a walking Work of Art, "Yorkshire Post" 15 August 2008. https://www.bing.com/search?q=Isabel Rawsthorne: The Women who was a walking Work of Art, "Yorkshire Post" 15 August 2008. - Bing (31.8.2021).

Jacobi Carol Picasso's Portraits of Isabel Rawsthorne, "The Burlington Magazine", 2017 September, vol. 159/No. 1374. https://www.burlington.org.uk/archive/article/picassos-portraits-ofisabel-rawsthorne (30.05.2021). 


\section{DYSKURS MIĘDZY I O ARTYSTACH: ALBERTO GIACOMETTI - FRANCIS BACON (streszczenie)}

Problem niniejszego artykułu zawiera się w skupieniu uwagi na pojęciu dyskursu w odniesieniu do życia i twórczości oraz wzajemnych związkach dwóch wybitnych artystów XX wieku: Alberto Giacomettiego i Francisa Bacona. Dyskurs o tych twórcach a także dyskurs między nimi stał się tematem - podstawą rozważań prezentowanego tekstu. W 2018 roku zorganizowana została wystawa (Bacon.Giacometti) konfrontująca dorobek obu mistrzów, w ramach której kuratorzy wskazali na podobieństwo ich postaw artystycznych, styl życia, więzi przyjaźni, rywalizację i wspólne wizje twórcze. Wspólna prezentacja twórczości tych dwóch artystów: Francisa Bacona i Alberto Giacomettiego w ramach jednej wystawy pozwoliła widzieć ich artystyczne dokonania i koleje losu z perspektywy rozumienia znaczenia pojęcia dyskursu. Wystawa ich prac miała miejsce w 2018 roku w Fondation Beyeler przy współudziale Fondation Giacometti w Paryżu. Pokaz ten, przy udziale najwybitniejszych badaczy zajmujących się twórczością obu artystów, stał się wizualnym i merytorycznym wskazaniem szczególnego dyskursu między i o życiu i twórczości Giacomettiego i Bacona.

Słowa klucze: Francis Bacon, Alberto Giacometti, dyskurs, proces kreacji, rzeźba, malarstwo, figura ludzka, pracownia.

Eleonora Jedlińska - PhD, after habilitation, professor at the Institute of Art History, University of Łódź. Lecturer in modern and contemporary art history, theory, and criticism of art. Member of the AICA, president of the Lódź branch of the Polish Institute for World Art Studies, member of the European Association of Jewish Studies and World Jewish Studies. Author of the books: Sztuka po Holocauście / Art after the Holocaust (2001), Polska sztuka wspótczesna $w$ amerykańskiej krytyce artystycznej w latach 1984-2002 / Polish contemporary art in American art criticism 1984-2002 (2005), Powszechna wystawa światowa w Paryżu w 1900 roku. Splendory Trzeciej Republiki / Universal World Exhibition in Paris in 1900. Splendors of the Third Republic (2015), Ksztatty pamięci. Wybrane zagadnienia sztuki wspótczesnej / The shapes of memory. Selected issues of contemporary art (2019). 